\title{
Technical Loss Reduction in Rural Areas - The Case of Saih Al Khairat
}

\author{
M.H. Albadi ${ }^{*}$, , A.H. Al Maghdria, A.S. Al Hinai ${ }^{a}$, E.F. El-Saadany ${ }^{b}$, M.S. Awladthanic, S. Al Hinai \\ A. Al Jabria, K. Al Azania, and A. Al Maqrashia \\ a Department of Electrical and Computer Engineering, College of Engineering, Sultan Qaboos University, PO Box 33, \\ Muscat-123, Sultanate of Oman. \\ ${ }^{b}$ Department of Electrical and Computer Engineering, University of Waterloo, 200 University Ave W, Waterloo, ON \\ N2L3G1, Canada. \\ c Real Areas Electricity Company, P.O. Box 1166, A'Seeb 133, Sultanate of Oman.
}

Received 31 October 2016; Accepted 6 March 2017

\begin{abstract}
This article investigates the potential for reducing technical losses in the rural area network of Saih Al Khairat in Thumrait, Oman. Based on the available network data, a power flow model of the system under study is built and the system performance is studied. To reduce losses and improve the voltage profile, different candidate solutions are investigated in coordination with the distribution system operator. An economic evaluation of the different options is conducted.
\end{abstract}

Keywords: Distribution systems; Rural areas; Loss minimization; Power flow; Reactive compensation.

$$
\begin{aligned}
& \text { الحد من المفاقيد التقنية يخ المناطق الريفية-حالة سيع الخيرات }
\end{aligned}
$$

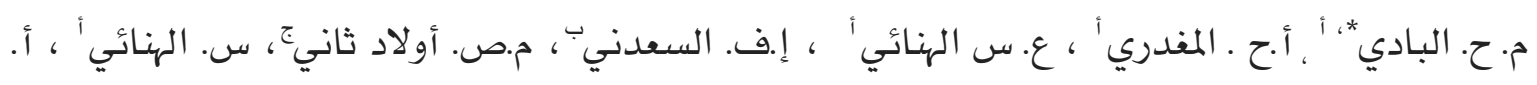

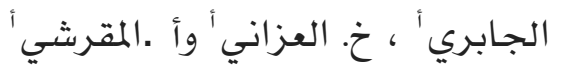

الملخص: تبحث هذه المقالة وِّ إمكانية الحد من المفاقيد التقنية وِّ شبكة المناطق الريفية وِّ سيح الخيرات ثمريت بسلطنة عمان .واستتادا إلى بيانات الشبكة المتاحة، تم بناء نموذج لتدفق الطاقة للنظام قيد البحث وتقييم أداء النظام •ومن أجل التقليل من المفاقيد وتحسين شكل الجهد، يتم البحث ِّْ الحلول المقترحة المختلفة بالتسيق مع مشغل نظام التوزيع • كها يجري تقييم اقتصادي لمختلف الخيارات. الكلمات المفتاحية: أنظمة التوزيع، المناطق الريفية، تقليل المفاقيد ، تدفق الطاقة، التعويض التفاعلي.

*Corresponding author's email: mbadi@squ.edu.om 


\section{Nomenclature}

$\begin{array}{ll}\text { AER } & \text { authority of electricity regulation } \\ \text { AMI } & \text { advanced metering infrastructure } \\ \text { DVR } & \text { dynamic voltage restorer } \\ \text { DPS } & \text { Dhofar power system } \\ I & \text { current in Amperes } \\ \text { MIS } & \text { main interconnected system } \\ \text { RAEC } & \text { Rural Areas Electricity Company } \\ \text { NPV } & \text { net present value } \\ \text { OMR } & \text { Omani Riyals } \\ \text { P } & \text { real power in Watt } \\ \text { PF } & \text { power factor } \\ \text { PP } & \text { payback period in years } \\ \text { Q } & \text { reactive power in VAR } \\ \text { S } & \text { apparent power in VA } \\ \text { UPFC } & \text { unified power-flow controller } \\ E_{S o u r c e} & \text { measured supplied energy in } \mathrm{kWh} \\ E_{l o a d} & \text { measured consumed energy in } \mathrm{kWh} \\ \left|V_{i}\right| & \text { voltage magnitudes at bus } i \text { in per unit } \\ \delta_{i} & \text { voltage angle at bus } i \text { in radian } \\ \left|Y_{i j}\right| & \text { magnitude of } Y \text {-bus element in per } \\ \theta_{i j} & \text { unit } \\ S_{L i j} & \text { angle of } Y \text {-bus element in radian } \\ F_{L s} & \text { losses in the branch } i-j \text { in per unit } \\ F_{L D} & \text { load factor } \\ P V_{A} & \text { present value of the recurring annuity } \\ & \text { A. }\end{array}$

\section{Introduction}

Losses in power systems are classified into two categories: technical losses and non-technical losses Al-Mahroqi, Metwally et al. (2012). Nontechnical losses result from actions external to power systems, for instance, human manipulation or mistakes in meter reading. Electricity theft is one of the main causes of nontechnical losses in some systems Antmann (2009). To reduce losses of this type, some utilities use automated meter reading and advanced metering infrastructure (AMI). In addition, it is possible to use data mining and intelligence-based techniques to detect and reduce non-technical losses Nagi, Mohammad et al. (2008). Even without AMI, non-technical losses can be estimated by comparing the measured energy consumption in a feeder with the energy that the utility bills plus technical losses Neto and Coelho (2013).

In comparison, technical losses are related to the physical characteristics and functions of the electrical network that result in the dissipation of electrical energy as heat. These types of losses occur mainly in low-efficiency equipment and in transmission and distribution lines. Technical losses can be classified as generation losses, transmission losses, and distribution losses. The causes of the technical losses include a low power factor, long lines, unbalanced loading, and overloading. An assessment of technical losses can be made with engineering calculations based on the design of the system. The majority of avoidable technical losses occur where the current is high.

Technical losses represent economic loss for utilities as generating more energy results in higher costs of generation. In addition, as losses result in the generation of more electrical energy to satisfy the generation-load balance requirement, high technical losses contribute to global warming.

According to the Authority of Electricity Regulation (AER), the total losses (technical and non-technical) in Oman's electricity sector were estimated to be $10.2 \%$ in 2015 , a decrease from $11.6 \%$ in 2014. Moreover, losses in the Main Interconnected System (MIS) decreased from $11.6 \%$ in 2014 to $10 \%$ in 2015, whereas the Rural Areas Electricity Company's (RAEC's) losses increased from $9.2 \%$ in 2014 to $10.7 \%$ in 2015 (AER 2016).

The main contributions of this article are listed below:

1. Modelling of a practical system in Oman during peak load condition. The system is known to have an under-voltage problem.

2. Simulating the system performance in terms of voltage profile and technical losses using ETAP ${ }^{\circledR}$ software package.

3. Simulating the system performance considering five solutions that aim for reducing system losses and improving voltage profile. These options were coordinated with the network operator.

4. Conducting a cost-benefit study of potential savings due to loss reduction for the considered options.

These options involve adding reactive compensation elements at selected buses as well as network reconfiguration by adding a new 11 
$\mathrm{kV}$ feeder. More details of these options are presented in section 5 .

Following this introduction, the paper presents a survey of sources of and mitigation techniques for technical losses in distribution systems. Section 3 presents the data of the system under study. As for section 4, it presents and discusses the results of the simulation of the network performance with different options. Finally, section 5 presents a summary of the main conclusions.

\section{Technical Loss Sources and Mitigation Techniques}

Technical losses in a power system result naturally from current flow through resistive materials as well as the nonlinear characteristics of some equipment in the grid. The most common example of technical loss is the power dissipated in transformers and transmission lines due to their internal resistance.

For example, the losses in a transmission line can be calculated by determining the difference between the measured energy injected from the source into the transmission line $\left(E_{\text {source }}\right)$ and the measured energy consumed $\left(E_{\text {load }}\right)$ by loads located at the end of that transmission line.

Losses $=E_{\text {source }}-E_{\text {load }}$

\subsection{Poor Power Factor}

In general, losses that occur in conductive materials can be decreased by reducing the current or by reducing the resistance. However, reducing the current is more effective as the loss formula $\left(I^{2} R\right)$ shows. The magnitude of the current is a function of the apparent power (S), which, in turn, has two components: real power $(\mathrm{P})$ and reactive power $(\mathrm{Q})$.

$|I|=|\mathrm{S}| / \sqrt{3}|\mathrm{~V}|$

$S=P+j Q$

The power factor $(\mathrm{PF})$ is related to the cosine of the angle between the voltage and the current or the ratio of the real power to the apparent power.

$P F=\frac{P}{S}$

$P F=\cos \left(\tan ^{-1} \frac{Q}{P}\right)$
The PF decreases as the ratio of reactive power to the real power increases. It is possible to achieve an improvement in PF by using devices, such as capacitors (switched/fixed) that deliver reactive power. A case study involving the reduction of losses using power factor correction was presented in Phetlamphanh, Premrudeepreechacharn et al. (2012). Figure 1 is a simple illustration of the reactive compensation concept.

Distribution utilities require customers to maintain a good (high) power factor to reduce losses. For example, industrial customers in Oman are obliged to maintain a power factor of at least 0.9 (AER 2016).

\subsection{Unbalanced Loads}

Distribution network losses can vary depending on the level of the balancing of the load. In an unbalanced operation mode, voltages and currents are not equally distributed between phases. Different factors can result in unbalanced operation modes. They include unequal phase loading and different line parameters in different phases.

Unbalance commonly occurs in three-phase distribution systems. However, it can be harmful to the operation of power systems. On the generation side, current asymmetry negatively affects efficiency. Unbalance reduces transmission capacity and efficiency Albadi, Hinai et al. (2015). In addition, it reduces the capacity and efficiency of the transformers. Zero sequence current is converted into a circulating current in a delta/wye-grounded transformer, resulting in increased losses.

There are several approaches to reduce the effects of unbalance. It is essential to adopt regulations and standards to ensure that all system components are designed and manufactured to be symmetrical. These components include generators, transformers,

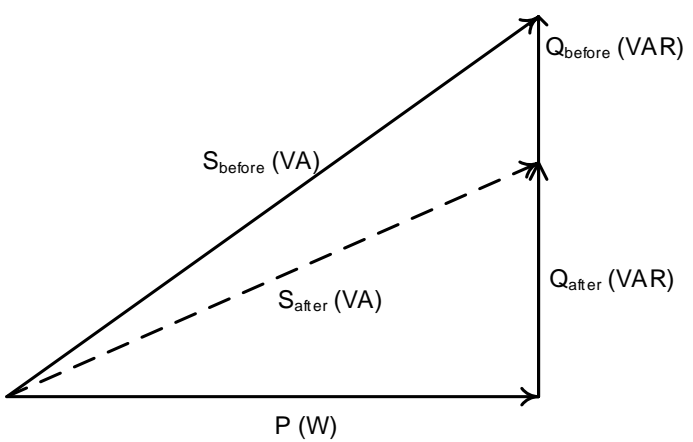

Figure 1. Illustration of the reactive compensation concept. 
transmission lines, three-phase motors, and switching equipment. In addition, imposing standards related to voltage and current unbalance levels is essential. These unbalance levels should be defined for both utilities and customers Albadi, Hinai et al. (2015). Another approach involves revising the connection of single-phase loads on the utility and customer sides. In addition, unbalance can be reduced by using balancing equipment such as single-phase voltage regulators, a dynamic voltage restorer (DVR), surge-protection devices, unified powerflow controllers (UPFC), and energy storage devices Kazibwe, Ringlee et al. (1990), Jouanne and Banerjee (2001).

\subsection{Transformers Losses}

In power distribution networks, the losses in transformers can reach $3 \%$ of the total electrical power generated (Ltd 2006). The transformer efficiency can be increased by reducing these losses. The losses in transformers can be classified in two different categories: the core loss or no-load loss category and the load or copper (winding) loss category Al-Badi, Elmoudi et al. (2011). Load losses are not highly sensitive to grid voltage changes, but they are highly sensitive to temperature variations. In the new distribution transformers, the secondary winding takes the form of a cylindrical sheet of aluminium. This is an important consideration in the adjustment of losses for temperature variation.

\subsection{Network/Feeder Reconfiguration}

In some cases, distribution network restructuring to minimize losses is highly costefficient. This option is of interest to efficiencyconscious electric utilities. Distribution feeders can be reconfigured by opening and closing switches while maintaining all load requirements (Ramesh, Chowdhury et al. 2009). To reduce power losses and improve voltage profile, both optimal feeder reconfiguration and optimal capacitor placement has been studied extensively using different optimization techniques Chang (2008). For example, genetic algorithms are used in Swarnkar, Gupta et al. (2010), Farahani, Vahidi et al. (2012). To overcome genetic algorithms drawbacks encountered in radial feeders' capacitor placement problem, authors in Fu-Yuan and Men-Shen (2005) used evolutionary programming. In Farahani, Vahidi et al. (2012), simulated annealing is used for joint reconfiguration and capacitor placement optimization. An ant colony algorithm is used in Kasaei and Gandomkar (2010) to solve feeder reconfiguration and capacitor placement optimization problem. Authors in Khalil, Gorpinich et al. (2013), and Sedighizadeh, Dakhem et al. (2014) used a selective particle swarm optimization to solve the optimization problem.

\section{System Data and Modelling}

The Rural Areas Electricity Company (RAEC) is an Omani closed joint stock company registered under the Commercial Companies Law of the Sultanate of Oman. The company commenced its operations on the $1^{\text {st }}$ of May, 2005, following the implementation of a decision that the Ministry of National Economy issued pursuant to the Regulation and Privatization of the Electricity and Related Water Sector law, which was promulgated by Royal Decree 78/2004 (RAEC 2016) (RAEC 2016). RAEC serves customers who are not connected to the Main Interconnected System (MIS) and Dhofar Power System (DPS). Its license and business activities are associated with generation, transmission, and distribution (RAEC 2016).

\subsection{System Data}

The system under study consists of 12 diesel generators $(4 \times 3 \mathrm{MW}$ and $8 \times 1 \mathrm{MW})$ and 103 transformers, as Table 1 indicates. The network has four feeders. One is a $33 \mathrm{kV}$ feeder and three are $11 \mathrm{kV}$ feeders. The $33 \mathrm{kV}$ feeder is operated and owned and operated by a large customer and was not modelled due to missing data. Three types of overhead transmission lines are used in the network. They are Panther, Wolf, and Dog ACSR conductors. Moreover, the underground cables in the $11 \mathrm{kV}$ feeders come in different sizes $\left(50,185,240\right.$, and $\left.500 \mathrm{~mm}^{2}\right)$. In the $33 \mathrm{kV}$ feeder, the underground cables have a size of $300 \mathrm{~mm}^{2}$.

Table 1. Network data summary.

\begin{tabular}{ll}
\hline Component & Numbers \\
\hline Diesel Generators & 12 \\
Transformers & 95 \\
Busses & 262 \\
Overhead Lines $(\mathrm{km})$ & 175.750 \\
Cables $(\mathrm{km})$ & 15.790 \\
Measured peak kW & 4975 \\
Measured peak kVAR & 3,784 \\
\hline
\end{tabular}


There are six $11 \mathrm{kV} / 415 \mathrm{~V}$ transformers, as Table 2 indicates. Appendices A and B present the details of the loading on these transformers. The single-line diagram is presented in the Appendix $C$, as is the per unit line data.

\subsection{Power Flow Model}

Power flow analysis is widely used in power system operation and planning. The power flow model of the system can be built using relevant network, load, and generation data. The outputs of the power flow model include voltages at different busses and line flows in the network. These outputs are obtained by solving power balance equations:

$P_{i}=\sum_{j=1}^{n}\left|V_{i}\right|\left|V_{j}\right|\left|Y_{i j}\right| \cos \left(\delta_{i}-\delta_{j}-\theta_{i j}\right)$

$Q_{i}=\sum_{j=1}^{n}\left|V_{i}\right|\left|V_{j}\right|\left|Y_{i j}\right| \sin \left(\delta_{i}-\delta_{j}-\theta_{i j}\right)$

where $\left|V_{i}\right|$ and $\left|V_{j}\right|$ are the magnitudes of the voltage at bus $i$ and $j$, respectively; $\delta_{i}$ and $\delta_{j}$ are the associated angles; $\left|Y_{i j}\right|$ is the magnitude of the $Y$-bus element between the two busses; and $\theta_{i j}$ is the corresponding angle.

These power balance equations are nonlinear; therefore, iterative techniques such as the Newton-Raphson, the Gauss-Seidel, and the fast-decoupled methods are commonly used Saadat (1999). In this case, ETAP ${ }^{\circledR}$ software package was used to model and evaluate the case study.

The system losses can be calculated once the power flow problem is iteratively solved. For example, the losses in the branch $i-j$ are the algebraic sum of the power flows.

$S_{L i j}=S_{i j}+S_{j i}$

where $S_{i j}=V_{i} I_{i j}{ }^{*}$ and $S_{j i}=V_{j} I_{j i}{ }^{*}$

\subsection{Load Data}

The load data of the power flow model were validated with the recorded data as shown in

Table 2. Transformer data summary.

\begin{tabular}{llll}
\hline & Numbers & X/R \% & Z\% \\
kVA & & & \\
\hline 1,000 & 6 & 5.10 & 4.75 \\
500 & 5 & 5.1 & 4.75 \\
315 & 69 & 3.97 & 4.75 \\
200 & 9 & 3.37 & 4.75 \\
100 & 5 & 2.32 & 4.75 \\
50 & 1 & 3.97 & 4.75 \\
\hline
\end{tabular}

Fig. 2. The difference between the measured data and that obtained from the model was about $8.7 \%, 2.35 \%$, and $0.2 \%$ for Feeders 1, 2, and 3 , respectively. These differences were due to records missing for some of the transformers. In addition, the recorded peak loads did not occur at the same time. Individual service transformer $(11 \mathrm{kV} / 415 \mathrm{~V})$ load data were included in the model to obtain the feeder load data.

\section{Results and Discussion}

\subsection{System Technical Losses}

Simulation results presented in Table 3 show that technical real power losses represented about $5.18 \%$ of the generated power, whereas the reactive power losses were $11.28 \%$ of the generated power. The distributions of these losses are given in Figs. 3 and 4.

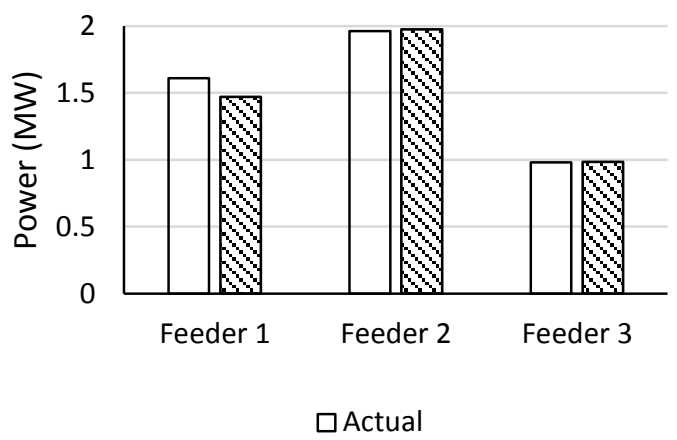

Figure 2. Recorded versus modelled data.

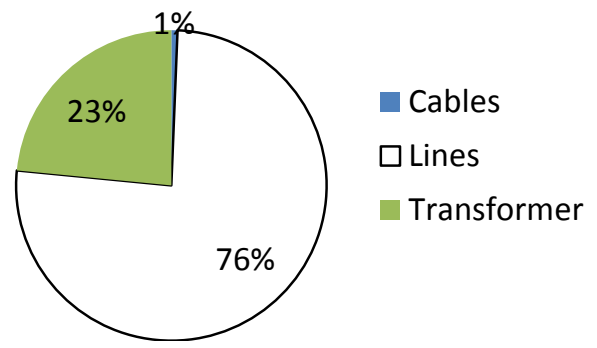

Figure 3. Distribution of power losses in the system.

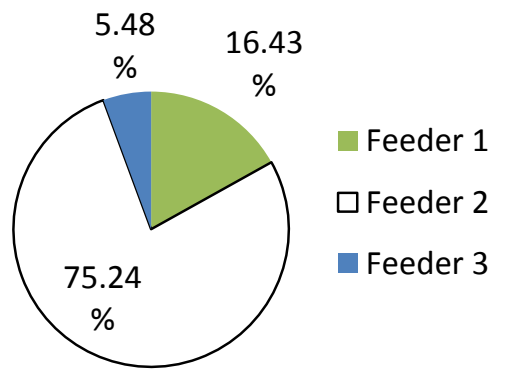

Figure 4. Distribution of losses in the feeders. 
It was clear that most losses occurred in the overhead line. This result was attributable to the fact that overhead lines dominated the rural area system. Another observation was that three quarters of the losses occurred in Feeder 2. This result was attributed to the long distances connecting the scattered loads in this feeder.

\subsection{Voltage Profile}

The Omani distribution code mandates that the voltage profile be within $6 \%$ of the nominal value in distribution networks $(33 \mathrm{kV}, 11 \mathrm{kV}$, and $415 \mathrm{~V})$ MJEC, MZEC et al. (2005). The Omani grid code allows for variation from the nominal value of up to $10 \%$ in transmission networks $(132 \mathrm{kV}, 220 \mathrm{kV}$, and $400 \mathrm{kV})(\mathrm{OETC}$ 2010).

The voltage profile at all busses is given in Fig. 5. The nominal voltage in this system was $11 \mathrm{kV}$. The voltage drop varied from one bus to another, depending on the loading of each bus and the distance from the power house. In general, the voltage drop was mostly due to the long distances between the service transformers in the network. The 6\% limit that the distribution code specified was violated at many busses, especially in Feeder 2.

The main reasons of having this low voltage problem are the growing demand and extension of feeders to connect new customers in this small isolated system. These substantial changes in this area are due to transferring some agricultural activities from Albatinah Governorate to Saih Al Khairat in Al Najd area, where an underground water reservoir was discovered. This transfer is aiming to conserve underground water in Albatinah Governorate and reduce air pollution caused by some agricultural activities. Therefore, to connect new customers, feeders were extended.

\subsection{Candidate Solutions}

Different options for reducing losses and improving the voltage profile were studied in coordination with RAEC. These options are listed below:

Table 3. Total supply, demand, and losses.

\begin{tabular}{llll}
\hline & Supply & Demand & Losses \\
\hline P (MW) & 4.975 & 4.553 & 0.422 \\
Q (MVar) & 3.7844 & 3.017 & 0.641 \\
S (MVA) & 6.092 & 5.325 & 0.7674 \\
\hline
\end{tabular}

Option 1: Adding $500 \mathrm{kVAR}$ to the existing 500 kVAR pole-mounted capacitor bank at Bus 66 .

Option 2: Installing a 1 MVAR pole-mounted capacitor bank in Feeder 2 at Bus 46 in addition to the existing $500 \mathrm{kVAR}$ capacitor bank at Bus 66.

Option 3: Installing two pole-mounted capacitor banks (1 MVAR each), one in Feeder 2 at Bus 46 and the other in Feeder 1 at Bus 40, in addition to the existing $500 \mathrm{kVAR}$ capacitor bank at Bus 66.

Option 4: Installing 3 pole-mounted capacitor banks, two 1MVAR capacitor banks in Feeder 2 at Bus 46 and one $500 \mathrm{kVAR}$ capacitor bank in Feeder 1 at Bus 40, in addition to the existing $500 \mathrm{kVAR}$ capacitor bank.

Option 5: Network reconfiguration by disconnecting Feeder 2 at Bus 34 and connecting a new $11 \mathrm{kV}$ Feeder (length: $30.97 \mathrm{~km}$ ) from the power station to the disconnected point.

The candidate buses for reactive compensation options are selected based on the network voltage profile and the network topology. The sizes of switched capacitors are based on standard sizes used by RAEC. The suggested new feeder connection point (bus 34) is based on distribution of loads and actual network topology.

The voltage profiles of these options in the peak loading condition are shown in Fig. 6 .

\subsection{System Performance with Different Options}

Figure 6 presents the improvements in voltage at different locations of the network using the different proposed options. It is clear that Option 2, Option 3, and Option 4 led to significant improvements in voltage. Hence, they will result in better compliance with $\pm 6 \%$ voltage limits, which, in turn, will result in increases in equipment lifetime and customer satisfaction.

\subsection{Economic Evaluation of Different Options}

Tables 4 and 5 show the losses and associated energy costs for the aforementioned options. The energy calculation can be performed by determining the loss factor $\left(F_{L S}\right)$ using the following equation (Gonen 2008).

$F_{L S}=0.84 F_{L D}^{2}+0.16 F_{L D}$

where $F_{L D}$ is the Load Factor. 


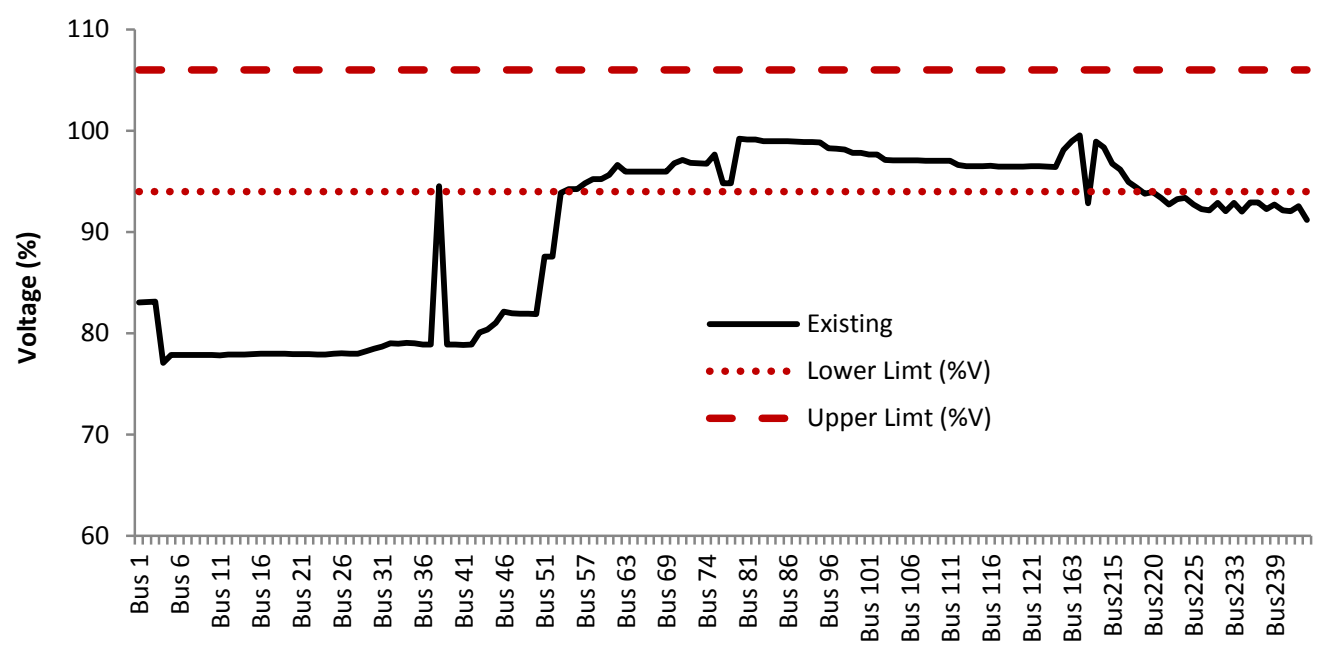

Figure 5. Voltage profile at all busses.

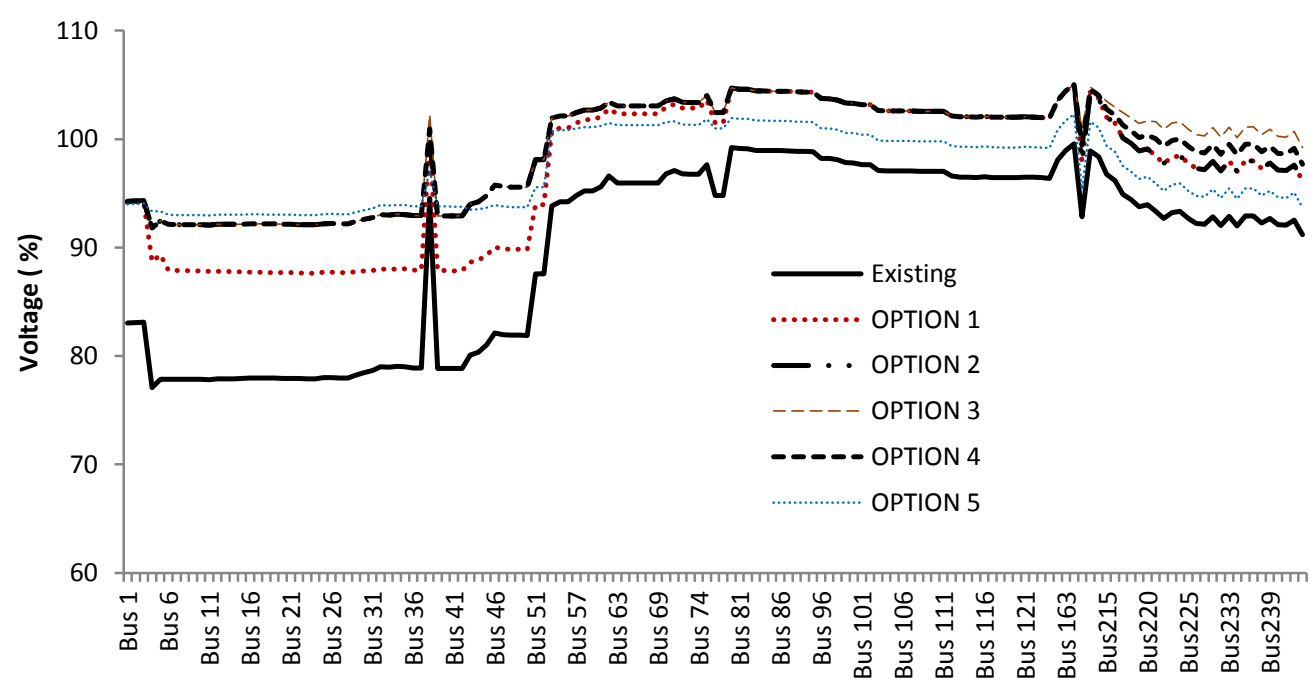

Figure 6. Voltage profile for different scenarios.

Once $F_{L S}$ is found, the average power loss can be calculated using the peak losses obtained from the power flow simulation. The load factor used in this study is 0.82 . Based on this value, the loss factor is 0.7 .

Average Loss $=\mathrm{F}_{\mathrm{LS}} *$ Peak loss

The annual energy loss can be calculated using the following formula:

Annual Energy Loss $=$ Average Loss $* 8760$

RAEC estimated the capital cost of the different options. It was estimated that the costs of the switched capacitor banks and the $11 \mathrm{kV}$ feeder were 14,000 OMR/MVAR and 13,000 OMR/km, respectively.

Using these values and the results from the previous table, the annual savings, payback period, and net present value were calculated based on the
$10.4 \%$ discount rate and 25-year lifetime that RAEC employed.

The net present value (NPV) was calculated for each option. The NPV of a project is the difference between revenues and costs in the current monetary value. In any comparison of investment options, the project with the maximum NPV is the winning one. For a recurring constant annual income, the present value can be found using the following formula:

Table 4. Reduction in losses.

\begin{tabular}{llc}
\hline Scenario & $\begin{array}{l}\text { Loss } \\
\text { (MW) }\end{array}$ & $\begin{array}{l}\text { Loss } \\
\text { Reduction (\%) }\end{array}$ \\
\hline Existing Network & 0.400 & $----^{--}$ \\
Option 1 & 0.377 & 5.75 \\
Option 2 & 0.351 & 12.25 \\
Option 3 & 0.336 & 16.0 \\
Option 4 & 0.337 & 15.75 \\
Option 5 & 0.233 & 41.75 \\
\hline
\end{tabular}


$P V_{A}=A \frac{(1+d r)^{N}-1}{d r(1+d r)^{N}}$

where $P V_{A}$ is the present value of the recurring annuity, $A$. In this context, the annuity refers to the annual savings with the implementation of different options.

The payback period (PP) is defined as the length of time required to recover the initial investment in a project. The shorter the length, the more economically attractive to investors the project is.

Another benefit of reducing losses is that it brings down fuel costs and subsidies. Additionally, the reduction of losses results in improved conditions for the immediate environment due to the reduction in power generation and $\mathrm{CO}_{2}$ emission.

The results presented in Table 6 show that any of the first four options would recover the costs within 2.5 years. The best option, which had the highest NPV, was Option 4. Although Option 5 had the largest annual savings, it was not economically attractive. This was because it was associated with a high capital cost.

\section{Conclusion}

The objective of the article was to investigate different candidate solutions for reducing technical losses and improving the voltage profile of a rural area distribution system. A model of the Saih Al Khairat network, which the Rural Areas Electricity
Company owns, was developed, and the load flow solution was obtained using ETAP $^{\circledR}$ software package. The network data was collected from the Rural Areas Electricity Company and the equipment manufacturers. To improve the voltage profile and reduce losses, five options were studied and ranked according to their economic feasibility. The best option among them was the installation of three pole-mounted capacitor banks: two in Feeder 2 and one in Feeder 1.

\section{Conflict of Interest}

The authors declare no conflicts of interest.

\section{Funding}

No funding was received for this project.

\section{Acknowledgment}

The authors would like to thank the Rural Area Electricity Company for providing the system data and for their support in achieving this work.

\section{References}

AER (2016), Authority of Electricity Regulation Annual Report 2015.

Table 5. Cost of losses for different scenarios.

\begin{tabular}{lccc}
\hline Scenario & Average Loss (MW) & Energy Loss (kWh/year) & Cost (OMR/year) \\
\hline Existing Network & 0.28 & 2452800 & 110,376 \\
Option 1 & 0.2639 & 2311764 & 104,029 \\
Option 2 & 0.2457 & 2152332 & 96,855 \\
Option 3 & 0.2352 & 2060352 & 92,716 \\
Option 4 & 0.2359 & 2066484 & 92,992 \\
Option 5 & 0.1631 & 1428756 & 64,294 \\
\hline
\end{tabular}

Table 6. Economic evaluation for different scenarios.

\begin{tabular}{ccccc}
\hline Scenario & $\begin{array}{c}\text { Installation Cost } \\
\text { (OMR) }\end{array}$ & $\begin{array}{c}\text { Savings } \\
\text { (OMR/Year) }\end{array}$ & $\begin{array}{c}\text { Payback Period } \\
\text { (Years) }\end{array}$ & $\begin{array}{c}\text { Net Present Value } \\
\text { (OMR) }\end{array}$ \\
\hline Option 1 & 7,000 & 6,347 & 1.5 & 48,881 \\
Option 2 & 14,000 & 13,521 & 1.5 & 105,052 \\
Option 3 & 28,000 & 17,660 & 2.5 & 127,496 \\
Option 4 & 21,000 & 17,384 & 1.5 & 132,066 \\
Option 5 & 402,610 & 46,082 & 24.1 & 3,138 \\
\hline
\end{tabular}


Al-Badi A, Elmoudi A, Metwally I, Al-Wahaibi A, Al-Ajmi H, Al Bulushi M (2011), Losses reduction in distribution transformers. Proceedings of the International MultiConference of Engineers and Computer Scientists, Citeseer.

Al-Mahroqi Y, Metwally I, Al-Hinai A, AlBadi A (2012), Reduction of power losses in distribution systems. World Academy of Science, Engineering and Technology 6: 498505.

Albadi M.H, Hinai A.S.A, Al-Badi A.H, Riyami M.S.A, Hinai S.M.A, Abri R.S.A (2015), Unbalance in power systems: Case study. IEEE International Conference on Industrial Technology (ICIT).

Antmann P (2009), Reducing technical and non technical losses in the power sector. Background Paper for the World Bank Group Energy Sector Strategy, the World Bank.

Chang C.F (2008), Reconfiguration and capacitor placement for loss reduction of distribution systems by ant colony search algorithm. IEEE Transactions on Power Systems 23(4): 1747-1755.

Farahani V.Bm Vahidi, Abyaneh H.A (2012), Reconfiguration and capacitor placement simultaneously for energy loss reduction based on an improved reconfiguration method. IEEE Transactions on Power Systems 27(2): 587-595.

Fu-Yuan, H. and T. Men-Shen (2005), A multiobjective evolution programming method for feeder reconfiguration of power distribution system. Proceedings of the $13^{\text {th }}$ International Conference on, Intelligent Systems Application to Power Systems.

Gonen T (2008), Electric power distribution system engineering. California, Taylor and Francis Group.

Jouanne A.v, Banerjee B (2001), Assessment of voltage unbalance. IEEE Transactions on Power Delivery 16(4): 782-790.

Kasaei M.J, Gandomkar M (2010), Loss reduction in distribution network using simultaneous capacitor placement and reconfiguration with aant colony algorithm. 2010 Asia-Pacific Power and Energy Engineering Conference.

Kazibwe W.E, Ringlee R.J, Woodzell G.W, Sendaula H.M (1990), Power quality: a review. IEEE Computer Applications in Power 3(1): 39-42.
Khalil, T.M, Gorpinich A.V, Elbanna G.M (2013), Combination of capacitor placement and reconfiguration for loss reduction in distribution systems using selective PSO. 22nd International Conference and Exhibition on Electricity Distribution (CIRED 2013).

Ltd D.E.C.P (2006), Best Practical ManualTransformers. Vadodara - 390007, India.

MJEC, MZEC, MEDC (2005), The Distribution Code, Version 1.000.

Nagi J, Mohammad A.M, Yap K.S, Tiong S.K, Ahmed S.K (2008), Non-technical loss analysis for detection of electricity theft using support vector machines. 2008 IEEE 2nd International Power and Energy Conference: Pecon, 1(3): 907-912.

Neto E.A.C.A, Coelho J (2013), Probabilistic methodology for technical and nontechnical losses estimation in distribution system. Electric Power Systems Research 97: 93-99.

OETC (2010). The Grid Code, Version 2.

Phetlamphanh V.S, Premrudeepreechacharn, Ngamsanroaj K (2012), Technical losses reduction of electrical distribution system in vientiane capital. 2012 International Conference on Renewable Energy Research and Applications (ICRERA).

RAEC (2016), Rural Area electricity Company. Available: http://www.reefiah.com/."

Ramesh L, Chowdhury S.P, Chowdhury S, Natarajan A.A, Gaunt C.T (2009), Minimization of power loss in distribution networks by different techniques. International Journal of Electrical, Computer, Energetic, Electronic and Communication Engineering 3(4): 7.

Saadat H (1999), Power system analysis, McGraw- Hill.

Sedighizadeh M, Dakhem M, Sarvi M, Kordkheili H.H (2014), Optimal reconfiguration and capacitor placement for power loss reduction of distribution system using improved binary particle swarm optimization. International Journal of Energy and Environmental Engineering 5(1): 1-11.

Swarnkar A, Gupta N, Niazi K.R (2010), Optimal placement of fixed and switched shunt capacitors for large-scale distribution systems using genetic algorithms. 2010 IEEE PES Innovative Smart Grid Technologies Conference Europe (ISGT Europe). 


\section{Appendix A: Branch data}

\section{Table A1: The per unit system branch data}

\begin{tabular}{|c|c|c|c|c|}
\hline From & To & $\mathrm{R}(\mathrm{pu})$ & $X(p u)$ & B (pu) \\
\hline M1 & 457 & 0.326492562 & 0.521906224 & 1.36722E-05 \\
\hline 457 & 213 & 0.056652893 & 0.091773945 & 5.74309E-07 \\
\hline 457 & 33 & 0.673791736 & 1.091498115 & $6.83045 \mathrm{E}-06$ \\
\hline 33 & 215 & 0.064961983 & 0.105234123 & 6.58541E-07 \\
\hline 33 & 35 & 0.574082645 & 0.929975972 & 5.81966E-06 \\
\hline 35 & 217 & 0.389771901 & 0.631404739 & 3.95124E-06 \\
\hline 35 & 38 & 0.143520661 & 0.232493993 & 1.45492E-06 \\
\hline 38 & 39 & 0.034324793 & 0.057795373 & 5.76642E-06 \\
\hline 39 & 40 & 0.270347107 & 0.568832638 & 3.79526E-06 \\
\hline 40 & 44 & 0.123909091 & 0.260714959 & 1.73949E-06 \\
\hline 44 & 45 & 0.054208264 & 0.061759603 & $3.4956 \mathrm{E}-07$ \\
\hline 45 & 47 & 0.255230579 & 0.290784798 & $1.64585 \mathrm{E}-06$ \\
\hline 47 & 49 & 0.347836364 & 0.396290786 & 2.24301E-06 \\
\hline 44 & 50 & 0.074536364 & 0.084919454 & $4.80645 \mathrm{E}-07$ \\
\hline 50 & 233 & 0.422372727 & 0.48121024 & $2.72366 \mathrm{E}-06$ \\
\hline 44 & 51 & 0.101380165 & 0.213312239 & 1.42322E-06 \\
\hline 51 & 52 & 0.006758678 & 0.014220816 & $9.48815 \mathrm{E}-08$ \\
\hline 52 & 54 & 0.074049587 & 0.064793388 & 3.90785E-05 \\
\hline 54 & 236 & 0.016198347 & 0.018016529 & 1.23554E-05 \\
\hline 54 & 235 & 0.026727273 & 0.029727273 & 2.03863E-05 \\
\hline 52 & 55 & 0.234094215 & 0.21715301 & 0.000103544 \\
\hline 55 & 56 & 0.195702479 & 0.171239669 & 0.000103279 \\
\hline 56 & 59 & 0.032793388 & 0.028694215 & 1.73062E-05 \\
\hline 55 & 57 & 0.221350413 & 0.252185046 & 1.42737E-06 \\
\hline 57 & 239 & 0.170082645 & 0.102396694 & 4.97665E-05 \\
\hline 57 & 58 & 0.584997521 & 0.66648905 & 3.77234E-06 \\
\hline 58 & 242 & 0.149072727 & 0.169838908 & 9.6129E-07 \\
\hline 40 & 41 & 0.328826446 & 0.365735535 & 0.000250814 \\
\hline 41 & 42 & 0.151272727 & 0.132363636 & 7.98318E-05 \\
\hline 42 & 221 & 0.128 & 0.112 & 6.75499E-05 \\
\hline 42 & 224 & 0.058181818 & 0.050909091 & 3.07045E-05 \\
\hline M1 & 71 & 0.498016529 & 0.799352537 & $1.60206 \mathrm{E}-05$ \\
\hline 71 & 72 & 0.883785124 & 1.431673536 & 8.95922E-06 \\
\hline 72 & 73 & 0.146542149 & 0.237388603 & $1.48555 \mathrm{E}-06$ \\
\hline 72 & 74 & 0.166181818 & 0.269203571 & $1.68464 \mathrm{E}-06$ \\
\hline 71 & 70 & 0.072515702 & 0.117470649 & 7.35115E-07 \\
\hline 70 & 62 & 0.045322314 & 0.073419156 & 4.59447E-07 \\
\hline 62 & 63 & 0.15107438 & 0.244730519 & 1.53149E-06 \\
\hline 63 & 64 & 0.083090909 & 0.134601785 & $8.4232 \mathrm{E}-07$ \\
\hline 64 & 67 & 0.203950413 & 0.330386201 & 2.06751E-06 \\
\hline 63 & 61 & 0.083090909 & 0.134601785 & 8.4232E-07 \\
\hline 61 & 58 & 0.092155372 & 0.149285617 & 9.34209E-07 \\
\hline 58 & 59 & 0.048343802 & 0.078313766 & 4.90077E-07 \\
\hline 58 & 57 & 0.099709091 & 0.161522143 & $1.01078 \mathrm{E}-06$ \\
\hline 77 & 78 & 0.355024793 & 0.57511672 & 3.599E-06 \\
\hline 57 & 51 & 0.696452893 & 1.128207693 & 7.06017E-06 \\
\hline 51 & 52 & 0.101219835 & 0.163969448 & $1.0261 \mathrm{E}-06$ \\
\hline 51 & 46 & 1.661818182 & 2.692035709 & 1.68464E-05 \\
\hline 46 & 47 & 0.400347108 & 0.648535875 & $4.05845 \mathrm{E}-06$ \\
\hline 47 & 48 & 0.203950413 & 0.330386201 & 2.06751E-06 \\
\hline 48 & 50 & 0.15107438 & 0.244730519 & 1.53149E-06 \\
\hline 48 & 49 & 0.007553719 & 0.012236526 & 7.65745E-08 \\
\hline 46 & 45 & 0.377685951 & 0.611826298 & 3.82873E-06 \\
\hline 45 & 44 & 0.190353719 & 0.374437694 & $2.34318 \mathrm{E}-06$ \\
\hline 44 & $44 \mathrm{G}$ & 0.028704132 & 0.046498799 & 2.90983E-07 \\
\hline $44 \mathrm{G}$ & $44 \mathrm{GH}$ & 0.012247934 & 0.003421488 & $1.01281 \mathrm{E}-06$ \\
\hline $44 \mathrm{G}$ & 43 & 0.090644628 & 0.146838311 & 9.18894E-07 \\
\hline 43 & 34 & 0.490991736 & 0.795374187 & 4.97734E-06 \\
\hline 34 & 35 & 0.045322314 & 0.073419156 & 4.59447E-07 \\
\hline 35 & 36 & 0.21452562 & 0.347517337 & 2.17472E-06 \\
\hline 36 & 37 & 0.021150413 & 0.034262273 & 2.14409E-07 \\
\hline 37 & $38 \mathrm{~L}$ & 0.045322314 & 0.073419156 & 4.59447E-07 \\
\hline $38 \mathrm{~L}$ & 39 & 0.039279339 & 0.063629935 & 3.98187E-07 \\
\hline $38 \mathrm{~L}$ & 40 & 0.024171901 & 0.039156883 & $2.45038 \mathrm{E}-07$ \\
\hline 40 & 42 & 0.045322314 & 0.073419156 & 4.59447E-07 \\
\hline 40 & 41 & 0.199418182 & 0.323044285 & 2.02157E-06 \\
\hline 34 & 32 & 0.019639669 & 0.031814967 & 1.99094E-07 \\
\hline 32 & 40 & 0.249272727 & 0.403805356 & $2.52696 \mathrm{E}-06$ \\
\hline 32 & 31 & 0.241719008 & 0.39156883 & $2.45038 \mathrm{E}-06$ \\
\hline 31 & 30 & 0.143520661 & 0.232493993 & $1.45492 \mathrm{E}-06$ \\
\hline 30 & 29 & 0.203950413 & 0.330386201 & 2.06751E-06 \\
\hline 29 & 26 & 0.211504132 & 0.342622727 & 2.14409E-06 \\
\hline
\end{tabular}

\begin{tabular}{|c|c|c|c|c|}
\hline 26 & 27 & 0.188842975 & 0.305913149 & 0 \\
\hline 27 & 28 & 0.001510744 & 0.002447305 & 1.53149E-08 \\
\hline 26 & 25 & 0.037768595 & 0.06118263 & 3.82873E-07 \\
\hline 25 & 17 & 0.007553719 & 0.012236526 & 7.65745E-08 \\
\hline 17 & 18 & 0.042300826 & 0.068524545 & 4.28817E-07 \\
\hline 18 & 19 & 0.009064463 & 0.014683831 & 9.18894E-08 \\
\hline 19 & 20 & 0.051365289 & 0.083208376 & 5.20707E-07 \\
\hline 20 & 21 & 0.13898843 & 0.225152077 & 1.40897E-06 \\
\hline 20 & 22 & 0.099709091 & 0.161522143 & 1.01078E-06 \\
\hline 22 & 23 & 0.086112397 & 0.139496396 & 8.72949E-07 \\
\hline 23 & 24 & 0.143520661 & 0.232493993 & $1.45492 \mathrm{E}-06$ \\
\hline 17 & 16 & 0.045322314 & 0.073419156 & 4.59447E-07 \\
\hline 16 & 15 & 0.06345124 & 0.102786818 & 6.43226E-07 \\
\hline 15 & 14 & 0.045322314 & 0.073419156 & $4.59447 \mathrm{E}-07$ \\
\hline 14 & $14 \mathrm{H}$ & 0.001510744 & 0.002447305 & $1.53149 \mathrm{E}-08$ \\
\hline 14 & 12 & 0.061940496 & 0.100339513 & 6.27911E-07 \\
\hline 12 & 13 & 0.339917355 & 0.550643668 & $3.44585 \mathrm{E}-06$ \\
\hline 12 & 9 & 0.078558678 & 0.12725987 & 7.96375E-07 \\
\hline 9 & 10 & 0.046833058 & 0.075866461 & $4.74762 \mathrm{E}-07$ \\
\hline 10 & 11 & 0.256826446 & 0.416041882 & 2.60353E-06 \\
\hline 9 & 7 & 0.030214876 & 0.048946104 & 3.06298E-07 \\
\hline 7 & 8 & 0.069494215 & 0.112576039 & 7.04485E-07 \\
\hline 7 & 6 & 0.052876033 & 0.085655682 & 5.36022E-07 \\
\hline 6 & 5 & 1.6210281 & 2.625958469 & 1.64329E-05 \\
\hline 5 & $4 \mathrm{~L}$ & 1.577216529 & 2.554986618 & $1.59888 \mathrm{E}-05$ \\
\hline $4 \mathrm{~L}$ & 3 & 0.175246281 & 0.283887402 & 1.77653E-06 \\
\hline 3 & 2 & 0.080824793 & 0.130930828 & 8.19347E-07 \\
\hline 2 & 1 & 0.114723141 & 0.18891979 & $3.0825 \mathrm{E}-06$ \\
\hline M1 & 80 & 0.33938843 & 0.542385492 & 1.44125E-05 \\
\hline 80 & 81 & 0.148052893 & 0.239835909 & $1.50086 \mathrm{E}-06$ \\
\hline 81 & 82 & 0.128413223 & 0.208020941 & 1.30177E-06 \\
\hline 81 & 83 & 0.389771901 & 0.631404739 & 3.95124E-06 \\
\hline 83 & 163 & 0.166181818 & 0.269203571 & 1.68464E-06 \\
\hline 84 & 85 & 0.206971901 & 0.335280811 & 2.09814E-06 \\
\hline 85 & 87 & 0.067983471 & 0.110128734 & 6.89171E-07 \\
\hline 85 & 86 & 0.086112397 & 0.139496396 & 8.72949E-07 \\
\hline 84 & 88 & 0.317256198 & 0.51393409 & 3.21613E-06 \\
\hline 88 & 95 & 0.261358678 & 0.423383798 & 2.64948E-06 \\
\hline 88 & 84 & 0.093666116 & 0.151732922 & 9.49524E-07 \\
\hline 80 & 96 & 0.61185124 & 0.991158602 & 6.20253E-06 \\
\hline 96 & 97 & 0.250783471 & 0.406252662 & 2.54227E-06 \\
\hline 96 & 98 & 0.077047934 & 0.124812565 & 7.8106E-07 \\
\hline 98 & 162 & 0.054386777 & 0.088102987 & $5.51336 \mathrm{E}-07$ \\
\hline 98 & 99 & 0.211504132 & 0.342622727 & $2.14409 \mathrm{E}-06$ \\
\hline 99 & 100 & 0.018884298 & 0.030591315 & $1.91436 \mathrm{E}-07$ \\
\hline 99 & 101 & 0.098198347 & 0.159074837 & 9.95469E-07 \\
\hline 101 & 102 & 0.024171901 & 0.039156883 & $2.45038 \mathrm{E}-07$ \\
\hline 101 & 103 & 0.419986777 & 0.680350843 & 4.25754E-06 \\
\hline 103 & 104 & 0.21452562 & 0.347517337 & 2.17472E-06 \\
\hline 104 & 105 & 0.392793389 & 0.636299349 & 3.98187E-06 \\
\hline 104 & 106 & 0.096687603 & 0.156627532 & 9.80154E-07 \\
\hline 106 & 107 & 0.022661157 & 0.036709578 & 2.29724E-07 \\
\hline 106 & 108 & 0.543867769 & 0.881029868 & $5.51336 \mathrm{E}-06$ \\
\hline 108 & 109 & 0.312723967 & 0.506592174 & 0 \\
\hline 108 & 110 & 0.045322314 & 0.073419156 & $4.59447 \mathrm{E}-07$ \\
\hline 110 & 111 & 0.249272727 & 0.403805356 & 2.52696E-06 \\
\hline 110 & $110 \mathrm{H}$ & 0.03172562 & 0.051393409 & 3.21613E-07 \\
\hline 103 & 112 & 0.403368595 & 0.653430486 & 4.08908E-06 \\
\hline 112 & 113 & 0.160138843 & 0.25941435 & $1.62338 \mathrm{E}-06$ \\
\hline 113 & 114 & 0.007553719 & 0.012236526 & 7.65745E-08 \\
\hline 114 & 115 & 0.126902479 & 0.205573636 & $1.28645 \mathrm{E}-06$ \\
\hline 112 & 116 & 0.090644628 & 0.146838311 & 9.18894E-07 \\
\hline 116 & 117 & 0.225100826 & 0.364648473 & 2.28192E-06 \\
\hline 117 & 118 & 0.01208595 & 0.019578442 & 1.22519E-07 \\
\hline 118 & 119 & 0.013596694 & 0.022025747 & 1.37834E-07 \\
\hline 118 & 120 & 0.191864463 & 0.310807759 & 1.94499E-06 \\
\hline 116 & 121 & 0.143520661 & 0.232493993 & 1.45492E-06 \\
\hline 121 & 122 & 0.280998347 & 0.455198765 & 2.84857E-06 \\
\hline 121 & 125 & 0.746307438 & 1.208968764 & 7.56556E-06 \\
\hline
\end{tabular}


Appendix B: Transformer Loading Data Table B1: Feeder 1 data

\begin{tabular}{lllll}
\hline SL. NO & Tx. No. & $\begin{array}{l}\text { Tx. } \\
\text { kVA }\end{array}$ & $\begin{array}{l}\text { Load } \\
(\mathbf{k W})\end{array}$ & Load (kVAR) \\
\hline 1 & 58 & 315 & 38 & 29 \\
2 & 44 & 315 & 36 & 29 \\
3 & 34 & 315 & 34 & 26 \\
4 & 21 & 200 & 34 & 25 \\
5 & 7 & 315 & 34 & 25 \\
6 & 92 & 315 & 67 & 51 \\
7 & 93 & 315 & 67 & 50 \\
8 & 98 & 315 & 8 & 6 \\
9 & 64 & 315 & 67 & 50 \\
10 & 66 & 315 & 67 & 50 \\
11 & 97 & 315 & 67 & 50 \\
12 & $3 G$ & 1000 & 159 & 121 \\
13 & $1 G$ & 1000 & 159 & 119 \\
14 & $1 G$ & 1000 & 159 & 119 \\
15 & $88 G$ & 500 & 40 & 30 \\
16 & 72 & 315 & 3 & 2 \\
17 & $5 G$ & 1000 & 158 & 121 \\
18 & 65 & 315 & 35 & 26 \\
19 & 67 & 315 & 102 & 77 \\
20 & $1 G$ & 1000 & 81 & 61 \\
21 & $4 G$ & 500 & 81 & 60 \\
22 & $3 G$ & 1000 & 33 & 25 \\
23 & $2 G$ & 500 & 81 & 60 \\
\hline
\end{tabular}

Table B2: Feeder 3 data

\begin{tabular}{|c|c|c|c|c|}
\hline SL. NO & Tx. No. & Tx. kVA & Load (kW) & Load (kVAR) \\
\hline 1 & 83 & 315 & 4 & 3 \\
\hline 2 & 82 & 315 & 3 & 2 \\
\hline 3 & 28 & 315 & 4 & 3 \\
\hline 4 & 18 & 315 & 54 & 40 \\
\hline 5 & 29 & 315 & 14 & 11 \\
\hline 6 & 71 & 315 & 2 & 1 \\
\hline 7 & 59 & 315 & 15 & 11 \\
\hline 8 & 35 & 68 & 40 & 30 \\
\hline 9 & 17 & 315 & 40 & 30 \\
\hline 10 & 16 & 315 & 71 & 54 \\
\hline 11 & 27 & 315 & 27 & 20 \\
\hline 12 & 79 & 315 & 33 & 25 \\
\hline 13 & 81 & 315 & 1 & 1 \\
\hline 14 & 9 & 315 & 38 & 28 \\
\hline 15 & 80 & 315 & 16 & 12 \\
\hline 16 & 104 & 315 & 68 & 51 \\
\hline 17 & 23 & 315 & 44 & 33 \\
\hline 18 & 69 & 315 & 127 & 95 \\
\hline 19 & 26 & 315 & 30 & 22 \\
\hline 20 & 60 & 315 & 145 & 109 \\
\hline 21 & 61 & 315 & 88 & 66 \\
\hline 22 & 53 & 315 & 53 & 40 \\
\hline 23 & 10 & 315 & 67 & 51 \\
\hline
\end{tabular}

Table B3: Feeder 2 data

\begin{tabular}{|c|c|c|c|c|}
\hline SL. NO & Tx. No. & Tx. kVA & Load (kW) & Load (kVAR) \\
\hline 1 & 14 & 500 & 183 & 137 \\
\hline 2 & 13 & 100 & 14 & 11 \\
\hline 3 & 12 & 100 & 0 & 0 \\
\hline 4 & 50 & 315 & 12 & 9 \\
\hline 5 & 38 & 200 & 19 & 15 \\
\hline 6 & 45 & 200 & 40 & 30 \\
\hline 7 & 2 & 200 & 30 & 22 \\
\hline 8 & 24 & 200 & 75 & 56 \\
\hline 9 & 3 & 50 & 7 & 5 \\
\hline 10 & 19 & 315 & 0 & 0 \\
\hline 11 & 54 & 315 & 76 & 8 \\
\hline 12 & 95 & 100 & 0 & 0 \\
\hline 13 & 39 & 200 & 11 & 34 \\
\hline 14 & 55 & 315 & 22 & 20 \\
\hline 15 & $4 \mathrm{~A}$ & 315 & 45 & 16 \\
\hline 16 & 4 & 315 & 27 & 20 \\
\hline 17 & 78 & 315 & 21 & 16 \\
\hline 18 & 1 & 315 & 42 & 31 \\
\hline 19 & 101 & 200 & 7 & 5 \\
\hline 20 & 48 & 315 & 55 & 42 \\
\hline 21 & 11 & 315 & 27 & 20 \\
\hline 22 & 25 & 315 & 21 & 16 \\
\hline 23 & 6 & 315 & 99 & 74 \\
\hline 24 & 49 & 315 & 23 & 17 \\
\hline 25 & 70 & 315 & 0 & \\
\hline 26 & 22 & 200 & 91 & 68 \\
\hline 27 & 37 & 315 & 36 & 27 \\
\hline 28 & 5 & 500 & 94 & 71 \\
\hline 29 & $5 \mathrm{~A}$ & 200 & 89 & 67 \\
\hline 30 & 107 & 315 & 0 & \\
\hline 31 & 32 & 315 & 70 & 53 \\
\hline 32 & 36 & 315 & 11 & 8 \\
\hline 33 & 57 & 315 & 0 & 0 \\
\hline 34 & 33 & 315 & 64 & 48 \\
\hline 35 & 73 & 100 & 39 & 30 \\
\hline 36 & 41 & 315 & 41 & 31 \\
\hline 37 & 40 & 315 & 67 & 50 \\
\hline 38 & 46 & 315 & 51 & 38 \\
\hline 39 & 15 & 315 & 43 & 32 \\
\hline 40 & 42 & 315 & 41 & 31 \\
\hline 41 & 68 & 315 & 18 & 13 \\
\hline 42 & 62 & 315 & 31 & 24 \\
\hline 43 & 51 & 315 & 10 & 7 \\
\hline 44 & 56 & 315 & 0 & 0 \\
\hline 45 & 43 & 315 & 8 & 6 \\
\hline 46 & 63 & 315 & 36 & 27 \\
\hline 47 & 20 & 315 & 113 & 85 \\
\hline 48 & 30 & 315 & 67 & 50 \\
\hline 49 & 31 & 315 & 24 & 18 \\
\hline
\end{tabular}




\section{Appendix C: Single-Line Diagram}

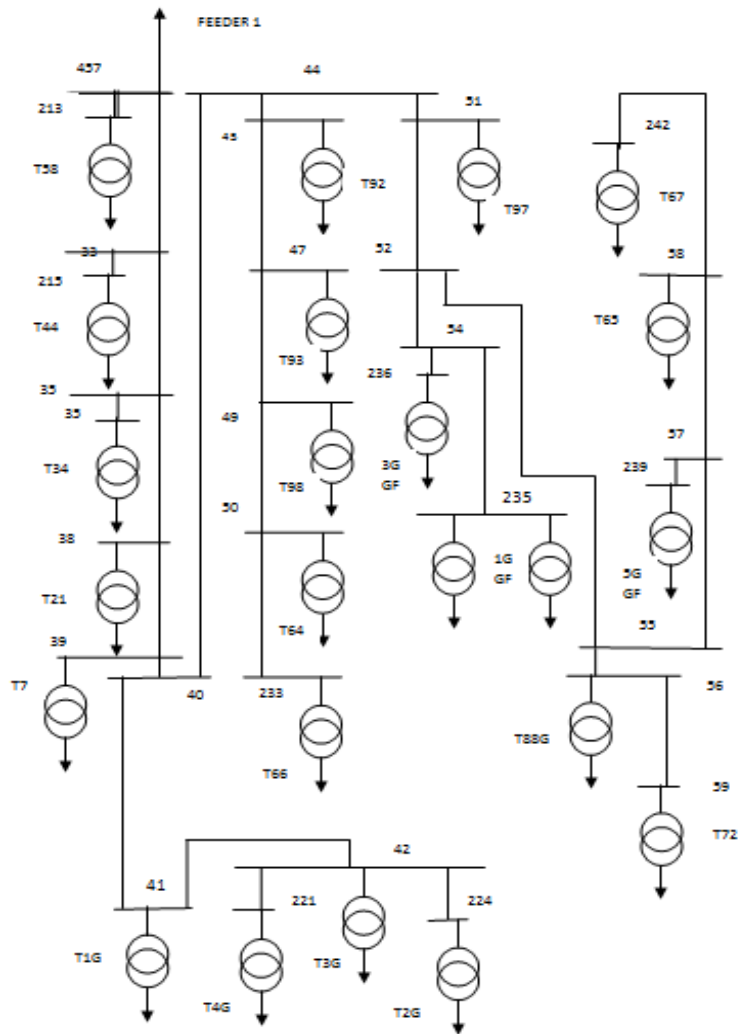

Figure C1: Feeder 1 SLD.

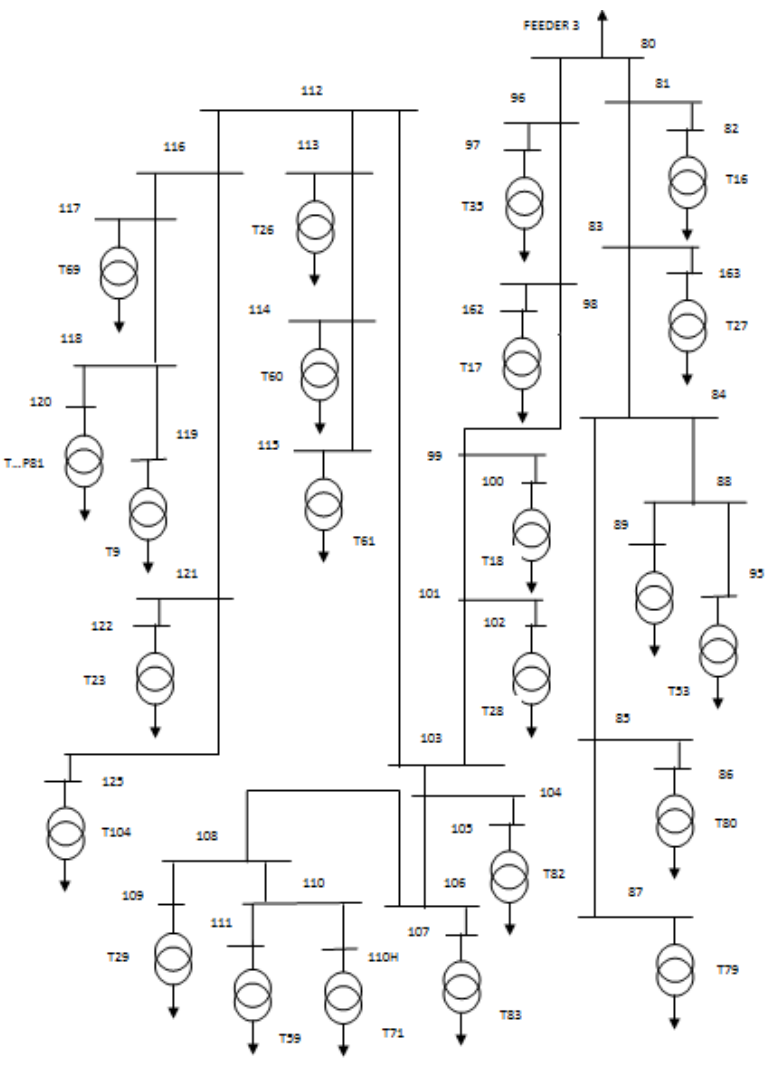

Figure C2: Feeder 3 SLD.

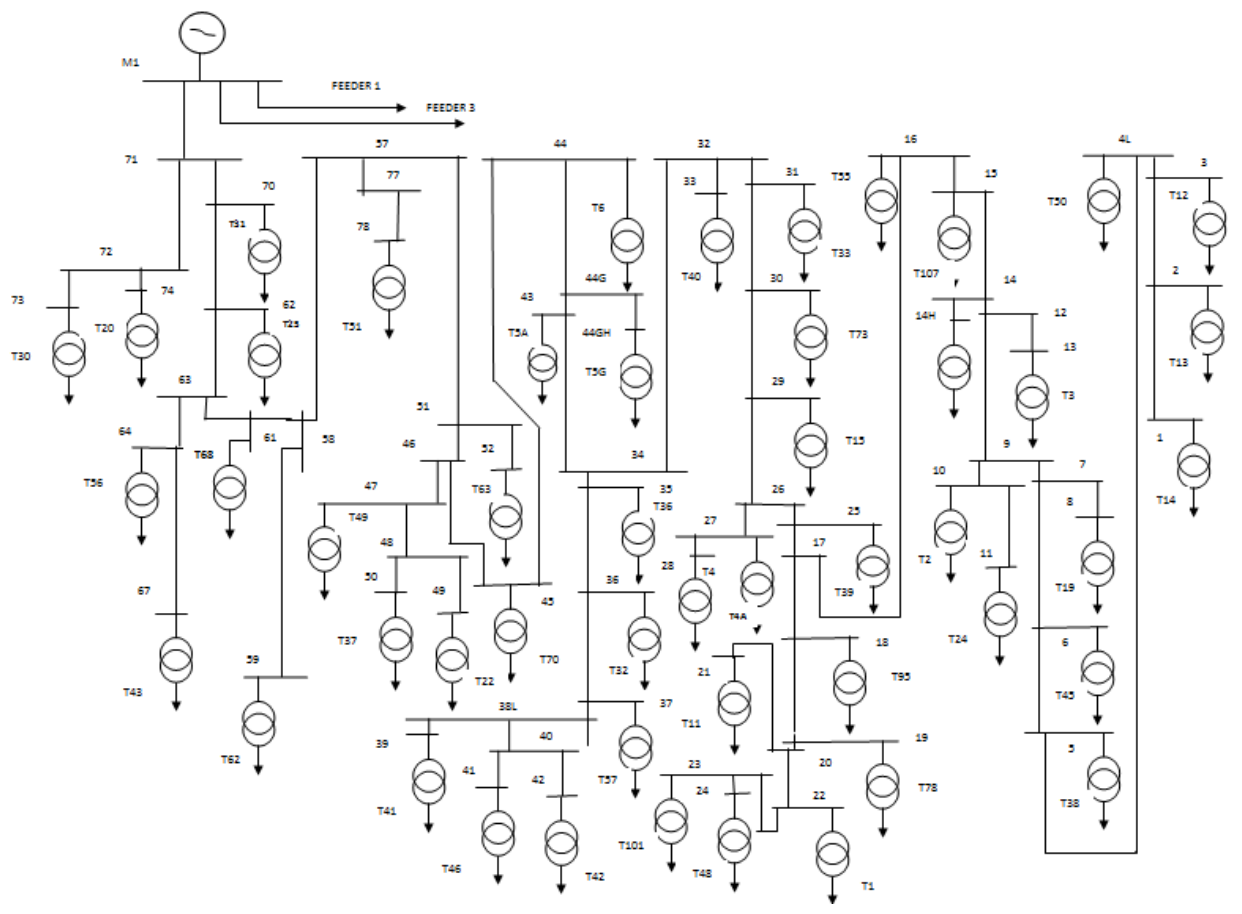

Figure C3: Feeder 2 SLD. 